\title{
The Librarian as Lobbyist
}

\author{
Eleonor E. Pasmik \\ Associate Librarian \\ NYU Medical Center Library
}

One of the goals of the Medical Library Association's Legislation Committee is to encourage members to become more involved in the political process and to experience the satisfaction it can bring when results are achieved. As librarians it is in our best interest to be well-informed on proposed and pending legislation affecting libraries. It is also our right and responsibility to make our views known to our elected representatives.

Legislators are sensitive to the views of their constituents and although one letter or one visit may not accomplish our goal, it does have an impact. The amount of mail received on an issue often helps determine the way a representative votes on a piece of legislation. Remember that a great many bills are introduced each year and it is impossible for a legislator to have in-depth knowledge of each bill.

Some of the information which follows pertains to U.S. federal legislation and legislators but the general principles apply on the state, provincial, or local level in the U.S., Canada, and other nations. Much of the material is derived from the pamphlets listed below.

\section{The Legislative Process-When to Write}

It is important to understand the legislative process in order to know when it will be most effective to contact legislators.

A bill may be written by an individual, an agency or a committee or subcommittee of one of the houses of Congress. Each bill is assigned to a committee which studies it and decides what action should be taken. Members of the committee should be contacted when the bill is about to come before the committee.

By calling the Bill Status Office in Washington, D.C., at (202) 225-1772 and referring to it by bill number, it is possible to find out the date a bill was introduced, the names of its sponsors or cosponsors, the date of committee hearings and the current status of the bill in the legislative process. The information is current to the previous twenty-four hours. Another way to determine the status of a bill is to call a member of the committee or subcommittee which is handling the bill.

After the bill comes out of committee, it is presented to the full House or Senate. When the bill is about to come before the House or Senate the representative should be contacted if it is a House bill or both senators if it is a Senate bill.

Legislation requiring federal funding must go through two processes: authorization and funding.
If Congress does not appropriate sufficient funds, or if executive agencies cut back on funds, a program can be seriously curtailed. For example, $\$ 16.5$ million was authorized for the Medical Library Assistance Act for the fiscal year 1980, but only $\$ 10.625$ million was appropriated in actual funding. Therefore, after a bill has been passed, it is important to state your views about the need for adequate funding to Congress or to the agency writing the regulations to implement the law.

It is important to lobby for appropriations before April 15 when the Budget Committees of the House and Senate report to their respective bodies the first resolution setting totals for government spending, revenues, deficit and level of public debt for the next fiscal year.

By May 15, the Budget Committees review various pieces of authorization legislation and by September 15, the second concurrent resolution establishes spending ceilings and a revenue floor. Keep these dates in mind to lobby for appropriations.

\section{To Obtain a Copy of a Bill}

A free single copy of a bill may be obtained from the Senate or House Document Room. Give the bill name and number, if possible, and enclose a self-addressed label with your request.

For a Senate bill, write to: Senate Document Room, U.S. Senate, Washington, DC 20510.

For a House bill, write to: House Document Room, House of Representatives, Washington, DC 20515.

\section{MeETING WITH LEgISLATORS}

Most legislators make frequent visits to their home districts. A personal visit with your member of Congress, either at the district office or in Washington, can establish pleasant rapport. Learn as much as you can about your legislators. Watch local newspapers for reports of the voting records of congressmen, read the newsletters legislators send out and take note of their committee assignments.

The following are suggested do's and don'ts to help insure a successful meeting:

- Do make an appointment by letter or phone and be on time.

- Do outline in your letter or phone call, the issues you wish to discuss at the meeting.

- Do prepare a concise, direct presentation which can be complete in a fifteen-minute meeting.

- Do be well-informed on all aspects of the issues you plan to discuss.

- Do be a good listener and ask for the legislator's point of view. 
- Do have a written statement of the points you wish to make and leave it with the legislator.

- Do leave on good terms even if you have not achieved your ends. You may join forces on another issue at another time.

- Don't be disappointed if your legislator cannot meet with you. Ask to see a legislative assistant who will be knowledgeable about the legislator's point of view and will convey your message to him.

- Don't be afraid to admit that you don't have some facts. Say that you will find the answers and report back and do so.

\section{Writing to Your Congressman}

Write the chairman or members of a committee holding hearings on legislation if you have facts which you hope will influence them. However, it is with your own representative or senators that you as a constituent have more influence. A personal letter in your own words is far better than a form letter.

Some fundamental do's and don'ts to keep in mind when writing legislators are listed below:

- Do address your senator or representative properly.

- Do identify the bill by number, subject, or popular title.

- Do share your expert knowledge on libraries and information services with your congressmen.

- Do include strong, factual, to the point arguments.
- Do be brief. Limit your letter to one or two pages.

- Do give your full name and address.

- Do write when you approve, not just to complain or oppose.

- Don't make threats or promises.

- Don't be vague.

The names of representatives and senators can be obtained from the local library, Board of Elections, or the League of Women Voters which has branches in every large city in the United States.

Suggested forms of salutation for letters to congressmen are:

\section{Senator:}

The Honorable Daniel Patrick Moynihan Senate Office Building

Washington, DC 20510

(Dear Senator Moynihan:)

Representative:

The Honorable Geraldine A. Ferraro House Office Building Washington, DC 20515

(Dear Mrs. Ferraro:)

\section{Suggested Reading}

The Citizen Lobbyist: A guide to Action in the State Capitol (1976). League of Women Voters of New York State, 817 Broadway, New York, NY 10003, \$1.35. The Citizen Lobbyist, while specifically on the New York State legislative process, includes material which has general applica-

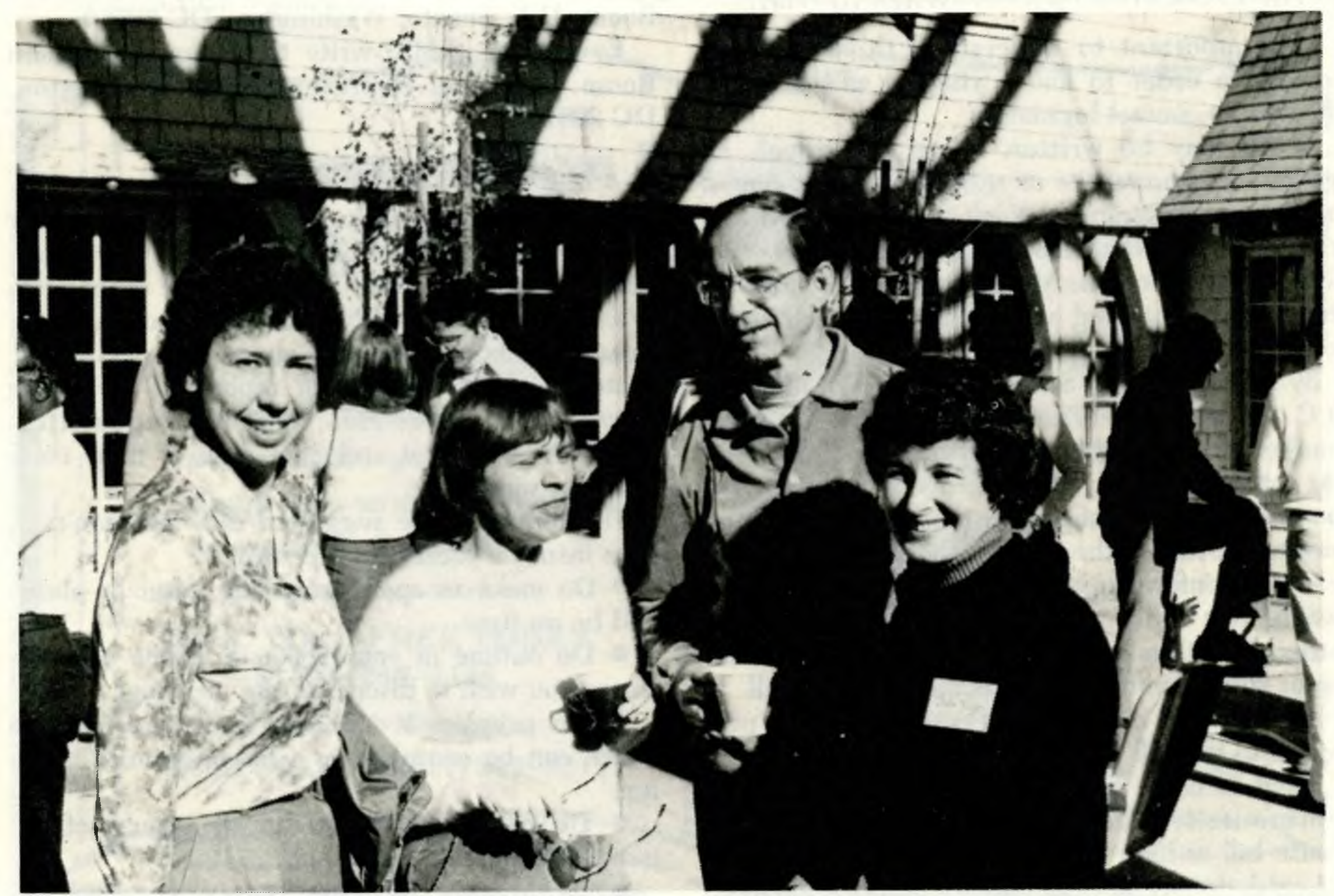

Left to right: Millicent Abell, Brooke Sheldon, David Weber, Julie Virgo, at Academic Libraries Frontier Conference. 
tion such as the use of memos and interviews, public relations, public hearings and how to plan and carry out a successful action campaign.

Guidelines for Meeting with Legislators, Pub. No. 21-1640; Guidelines for Writing to Your Congressman, Pub. No. 21-1641; Guidelines for Presenting Testimony on Legislation, Pub. No. 21-1642 (1976). National League for Nursing, Ten Columbus Circle, New York, NY 10019, \$.25 each, plus handling. This series of three Government Relations Pamphlets published by the National League for Nursing provide excellent checklists of do's and don'ts with some elaboration on each point.

The Library Lobbyist (1977). New York Library Association, 15 Park Row, Suite 434, New York, NY 10018, \$.75. This booklet is designed to be a practical guide for librarians, trustees and patrons working with the New York State Legislature and other levels of government.

Tell It to Washington: A Guide for Citizen Action Including Congressional Directory 1981-82, Pub. No. 349 (March 1981). League of Women Voters of the United States, 1730 M Street, N.W., Washington, DC 20036. \$1.00. Tell It to Washington includes a congressional directory, a list of congressional committees and their members, information on the legislative and budget processes and tips on writing to and visiting legislators.

Contact the League of Women Voters for their list of publications on local and national government.

Editor's Note: This article was originally published in the November-December 1981 issue of the MLA News.

\section{Academic Libraries Frontier Conference}

\section{FROM THE EXECUTIVE DIRECTOR:}

In December, forty-nine people with major responsibilities in management of academic research libraries, and their counterparts in library education, participated in the Academic Libraries Frontier Conference for 1981. Funded by the Council on Library Resources and planned by Robert Hayes, dean of the Graduate School of Library and Information Science at UCLA, the group met with the objective of identifying issues of mutual concern. The agenda included:

- What are the issues of importance?

- If they represent problems, are there evident means for solution of them?

- What research may be needed to provide the data needed for future decisions concerning the issues?

- What are the requirements for education that will provide upcoming generations with the knowledge and skills needed to deal with the issues?

Six commissioned papers were presented during the morning sessions, as a backdrop for the small working groups and informal evening sessions. William Gerberding, president of the University of Washington, spoke on the experience of retrenchment. He cautioned the group: "If you are going to get through the next period you are going to have to do it alone because presidents don't have a future view that will be helpful."

Jerald Stevens, the vice-president for finance at Yale, speculated on the economic environment over the next twenty years. He predicts that a lower rate of growth will make the U.S. economy unable to absorb the social programs of the past and that education will be unable to maintain its share of the economy. He anticipates that student demand will govern trends in higher education with a shift to vocational education. There will be a reduction in scholarly output, an impulse to centralize educational systems and libraries, and libraries may become an entry point for contractual services in educational institutions. Other papers by William Schaefer, Howard Resnikoff, and John Brademas dealt with the student population, information technologies, and the political environment, respectively.

The concluding paper by Steven Muller, president of Johns Hopkins University, provided a provocative view of the library's future, wherein the university will have at its heart a communications center. The question posed was where will that communications center be? Can the library expand to be the information center of the university? The university will need to have a computing service that does more than research and serve the administration. Whether the library or the computer center will serve as the communications/information center will depend on which one outperforms in service.

The ideas from the work groups will be synthesized and included in the proceedings of the conference. Edited by Robert Hayes, the publication will appear this year. As Dick Dougherty said in summing up the conference, "At this point we don't know how successful the conference waswhether we approached the frontiers or crossed them." Certainly it was a unique gathering of library administrators and library educators.Julie Carroll Virgo. 